\title{
Structural trends and basement rock subdivisions in the western Gulf of St. Lawrence, northern Appalachians
}

\author{
Paul W. Durling and François J.Y. Marillier \\ Atlantic Geoscience Centre, Geological Survey of Canada, Bedford Institute of Oceanography, \\ P.O. Box 1006, Dartmouth, Nova Scotia B2Y 4A2, Canada
}

Date Received November 20, 1989

Date Accepted February 12, 1990

\begin{abstract}
We compiled industry seismic and LITHOPROBE deep seismic data in the southwestem Gulf of St. Lawrence, and interpreted them together with gravity, magnetic and industry well data, to study the deepest sediments, which are assignable to the Horton Group of Late Devonian-Early Carboniferous age, and the basement rocks of the northern Appalachians.

Three upper crustal basement blocks with differing seismic character and orientation of geological structures were identified. South of the Appalachian structural front and parallel to it, two blocks with a northwest regional strike were interpreted to be allochthonous on Grenvillian crust. The basement block immediately south of the Appalachian structural front (Laurent) shows deformations compatible with Acadian or older northward thrusting, whereas the second (Bradelle) displays north dipping reflections, possibly related to formation of the Magdalen Basin. These basement blocks may contain the offshore extensions of either the Humber or Dunnage Appalachian terranes, or both.

The Catamaran, Fredericton, and Belleisle faults in New Brunswick appear to extend to the northeast across the third basement block (Shediac), parallel to the main structural trends in this block. The Shediac block contains the extensions of the Gander and Avalon terranes, and the deep seismic data suggest that the Gander/Avalon boundary cuts through the entire crust.

This compilation enabled us to address the problem of the formation of the Magdalen Basin. Several Horton Group subbasins, bounded by normal faults, indicate a widespread crustal extension phase which coincided with the early development of the Magdalen Basin. Compressive strike-slip movement inferred from the seismic data along the Belleisle Fault suggested that this fault played a major role in the formation of the basin, but crustal stretching occurred in an area not bounded by this fault. The overall asymmetry of the Magdalen Basin suggests that dip-slip movement occurred along a fault (the Hollow Fault?) bounding the basin to the east. The existence of a "Canso Fault" at the location proposed by several authors is not supported by our work. A better candidate for its location may be along the Bradelle/Shediac basement block boundary.
\end{abstract}

Nous avons compilé les données acquises à l'aide de la sismique industrielle et de la sismique à forte pénétration LITHOPROBE en provenance du sud-ouest du Golfe du Saint-Laurent, les avons interprété en conjonction avec les données gravitaires, magnétiques et de forage industriel, et ce dans le but d'étudier les sédiments les plus profonds, attribuables au Groupe de Horton d'âge dévonien tardif à carbonifere précoce, ainsi que les roches constituant le socle dans les Appalaches septentrionales.

On identifia trois blocs de socle supracrustaux montrant des configurations sismiques et une orientation des structures géologiques différentes. On interprète comme allochtones sur une croûte grenvillienne deux blocs ayant une direction régionale nord-ouest, situés au sud du front structural appalachien et parallèles à ce dernier. Le bloc de socle sis juste au sud du front structural appalachien (bloc de Laurent) montre des déformations compatibles avec un chevauchement vers le nord acadien ou plus ancien, alors que l'autre bloc (bloc de Bradelle) présente des réflexions pentées nord et reliées possiblement à la formation du Bassin de la Madeleine. Ces blocs de socle pourraient contenir les extensions vers le large des lanières appalachiennes de Humber et/ou de Dunnage.

Les failles de Catamaran, de Fredericton et de Belleisle, au Nouveau-Brunswick, semblent se prolonger vers le nord-est par-delà le troisième bloc de socle (bloc de Shediac); elles sont parallèles aux principales tendances structurales à l'intérieur de ce bloc. Le bloc de Shediac contient les prolongements des lanières de Gander et d'Avalon; les données de la sismique à forte pénétration suggèrent que la frontière Gander/Avalon traverse toute l'écorce.

Cette compilation nous a permis d'envisager le problème de la formation du Bassin de la Madeleine. Plusieurs petits sousbassins, appartenant au Groupe de Horton et limités par des failles normales, indiquent une phase répandue d'extension crustale qui coïncida avec l'amorce du Bassin de la Madeleine. Un décrochement en compression, inféré des données sismiques, le long de la Faille de Belleisle suggère que cette faille joua un rôle majeur dans la formation du bassin bien que l'étirement crustal survint

Geological Survey of Canada Contribution No. 50489

ATLANTIC GEOLOGY

$26,79-95(1990)$ 
dans une région non limitée par cette faille. L'asymétrie d'ensemble du Bassin de la Madeleine suggère que le mouvement selon le rejet-pente se produisit le long d'une faille (Faille de Hollow?) limitant le bassin à l'est. Nos travaux ne confortent pas l'hypothèse d'une "Faille de Canso" à l'endroit avancé par plusieurs auteurs. Un meilleur site pour sa localisation serait le long de la frontière entre les blocs de socle de Bradelle et de Shediac.

[Traduit par le joumal]

\section{INTRODUCTION}

The basement rocks of the northern Appalachian orogen are in places concealed by a sequence of Upper Devonian to Permian sediments belonging to the Maritimes Basin (Roliff, 1962). This basin comprises several basins, the largest of which is the Magdalen Basin that covers the southern part of the Gulf of St. Lawrence. The sedimentary fill of the Magdalen Basin is represented by the continental redbeds of the Horton Group (Eifelian to early Visean), the mainly marine evaporite deposits of the Windsor Group (middle Visean to early Namurian), and the continental redbeds of the Canso, Riversdale, Cumberland and Pictou groups (Namurian to Permian) (Howie and Barss, 1975). Recent studies indicate that the maximum thickness of the Magdalen Basin is in the order of $12 \mathrm{~km}$ (Howie, 1988).

Several explanations have been proposed for the formation of the Magdalen Basin, the most notable of which are a subsidence model (McCutcheon and Robinson, 1987) and a pull-apart model (Bradley, 1982). In the former model the Magdalen Basin subsided as a result of Acadian continental collision in the latter model, whereas the Magdalen Basin developed between northeast trending, dextral strike-slip faults transecting the Gulf of St. Lawrence (i.e., approximately parallel to the strike of the Appalachian orogen at large). To test these models, the faulting style, the distribution of sediments and the offshore extensions of large faults in New Brunswick, like the Catamaran, Fredericton, and Belleisle faults, must be investigated (Fig. 1).

The Appalachian orogen is divided into five main terranes or tectono-stratigraphic zones: Humber, Dunnage, Gander, Avalon and Meguma (Williams, 1979; Williams and Hatcher, 1983). These divisions are based on a model for the closing of the Early Paleozoic Iapetus ocean during the Taconian and Acadian orogenies. The width of the Humber, Dunnage, Gander and Avalon terranes varies dramatically across the Gulf of St. Lawrence (Fig. 1). Although researchers have attempted to locate terrane boundaries and their probable extensions in the Gulf on the basis of potential field data controlled by geology and regional tectonic studies on land (e.g., Haworth and Lefort, 1979; Barr and Raeside, 1986), the location of these boundaries remains largely unknown. Marillier et al. (1989) interpreted deep seismic reflection profiles shot in the Gulf of St. Lawrence and northeast of Newfoundland (Keen et al., 1986), to derive a model in which three major lower crustal blocks (Grenville, Central and Avalon) form the lower crust of the Canadian Appalachians. These studies provided some insight into the third dimension of the northern Appalachians, but the widely spaced profiles did not allow detailed mapping.

Recently, a fault approximately perpendicular to the trend of the orogen was proposed in the southern Gulf of St. Lawrence. The "Canso Fault" (McCutcheon and Robinson, 1987), named

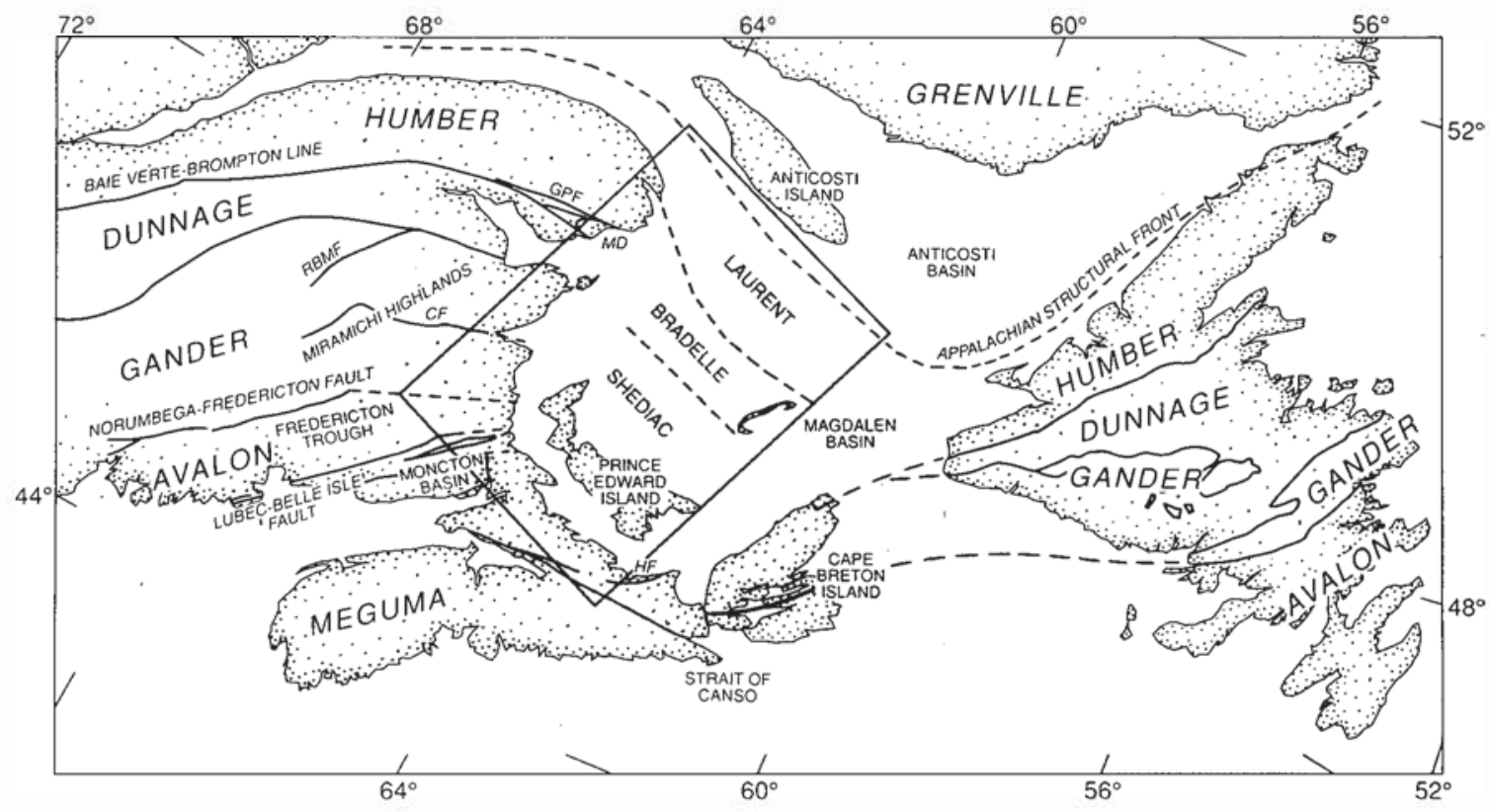

Fig. 1. Location map of the Northem Appalachians showing Appalachians terranes (Williams and Hatcher, 1983; Williams et al., 1988; Loncarevic et al., 1989), the Appalachian structural front (after Haworth, 1978; SOQUIP, 1987), main faults, and three upper crustal basement blocks in the Gulf of St. Lawrence: Laurent, Bradelle, and Shediac. CF - Catamaran Fault, GPF - Grand Pabos Fault, HF - Hollow Fault, MD - Maquereau Dome, RBMF - Rocky-Brook-Millstream Fault. The stippled area denotes the extent of the Maritimes Basin. 
after the Strait of Canso, was introduced to account for the offset of the Avalon/Gander boundary between New Brunswick and Cape Breton Island, and to explain the difference in geology between Cape Breton Island and northern Nova Scotia (Barr and Raeside, 1986; McCutcheon and Robinson, 1987; Stockmal et al., 1990).

The purpose of this paper is to investigate the nature and distribution of basement rocks and the faulting style beneath the Gulf of St. Lawrence using seismic reflection, gravity, magnetic and well data. We relate our findings in the Gulf to the geology on land to infer the offshore extension of terrane boundaries, and to identify features relevant to the development of the Magdalen Basin.

\section{THE SEISMIC DATA}

We compiled more than $18,000 \mathrm{~km}$ of industry seismic data (Fig. 2). Only a few seismic profiles shown in Figure 2 were not available to us. Most of the data were collected in the late 1960's and early 1970's by a number of exploration companies. In the early 1980's, Chevron carried out several surveys producing high quality data. Seismic data collection and processing techniques have evolved greatly over the past 30 years. Hence, the seismic data quality in the Gulf is not uniform and the pre-Carboniferous basement was difficult to define in places. Basement was interpreted on the seismic profiles wherever the flat lying reflections of the Upper Devonian and Carboniferous strata gave way to steeply dipping, folded or incoherent reflections. The recurrence of some seismic patterns and the identification of some features that could be mapped over large distances, gave us confidence in our observations. In addition to the industry data, we used deep seismic profiles of the Canadian LITHOPROBE program (Marillier et al., 1989) to provide deep crustal control.

Stratigraphic control was provided by two industry wells, Bradelle L-49 (Shell Canada Limited, 1974) and Irishtown No. 1 (Hudson's Bay Oil and Gas Company Limited, 1973). These wells (Fig. 3a) reach strata of the Horton Group, and time-depth correlations are available allowing direct correlation with the seismic profiles.

\section{DESCRIPTION OF BASEMENT BLOCKS}

We divided the basement rocks in the western half of the Gulf of St. Lawrence into three upper crustal basement blocks: Laurent, Bradelle and Shediac (Fig. 1). These divisions were based on the seismic character, orientation of geological structures and subsurface relief of the basement rocks (Fig. 3a). Strata of the Horton and lower Windsor groups were also studied since they locally reveal details on the timing of basement movements (Fig. 3b). We used gravity and magnetic data to derive the continuity of some features where seismic data were absent or not reliable. We also used them to discriminate between several possible interpretations as well as to extend trendsobserved in the seismic data; such extensions are dashed on our maps (Figs. 3a, 3b).

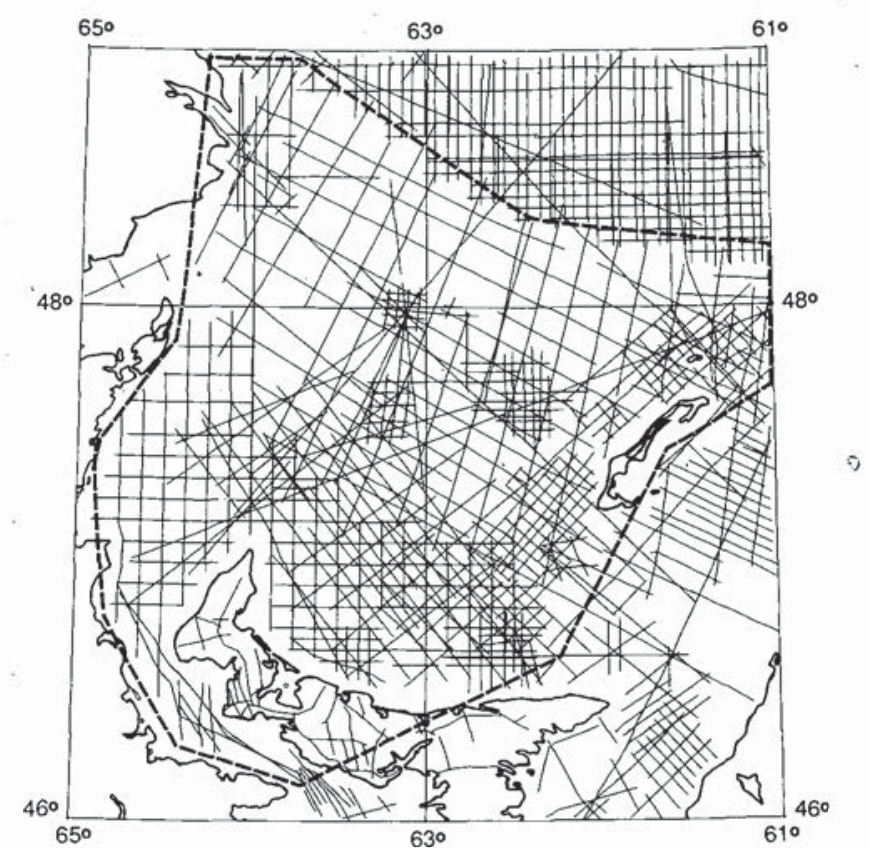

Fig. 2. Map showing the location of seismic lines in the southwestern Gulf of St. Lawrence. The dashed line outlines the area of data compilation.

\section{The Laurent block}

Laurent, the northernmost basement block, is bounded to the north by the Appalachian structural front and is oriented in a northwest-southeast direction (Fig. 3a) parallel to the gravity and magnetic trends in this area (Figs. 4, 5). It is characterized by strong negative and positive gravity anomalies and by positive magnetic anomalies. In the Gulf much of the gravity data were collected at a regular station spacing of $13 \mathrm{~km}$ (Goodacre and Nyland, 1966).

To the south, the Laurent block terminates against a north dipping reverse fault possibly offset by sinistral strike-slip faults (Fig. 3a). Strike-slip faulting is inferred from the offset of similar features on adjacent seismic profiles. The fault along the southem boundary of Laurent, is indicated by weak discontinuous seismic reflections (labelled 'A', Fig. 6) that terminate beneath a Horton subbasin. This relationship was seen on several adjacent seismic lines, and we defined the southern boundary of Laurent at the deepest point of the Horton Group subbasin. To the east of the Bradelle L-49 well, where this subbasin is absent (Figs. 3a, $3 b$ ), the boundary was defined at the intersection of the (A) reflections with the southeast dipping basement surface.

The (A) reflections can be traced northward at depth where they flatten and merge with high amplitude seismic reflections of the Anticosti Basin (SOQUIP, 1987). To the north, the (A) reflections represent the top of the Grenville block (Fig. 7, shot points 1500-2400), whereas in the south (Fig. 7, shot points 2850 to 3100 and Fig. 6,0 to $33 \mathrm{~km}$ ) the reflections represent a structural contact where Laurent rests on Bradelle. Between shot points 2400 and 2850 (Fig. 7) the high amplitude reflections 


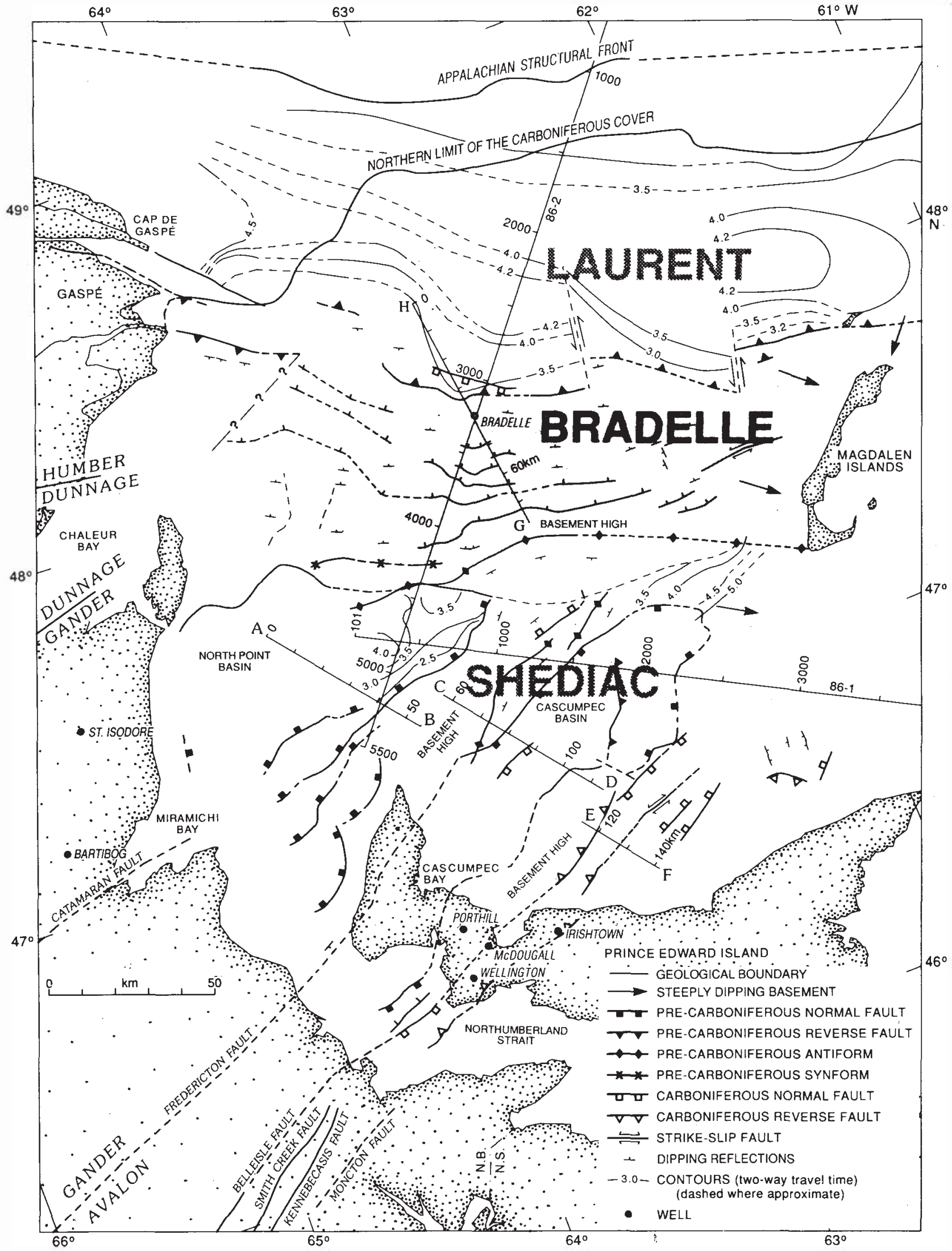

Fig. 3a. Structural map of Upper Devonian-Lower Carboniferous and older rocks in the southwestern Gulf of St. Lawrence inferred from seismic data. Gravity and magnetic data were also used as a guide. Lines with labeled tick marks denote seismic profiles. Location of this map is shown by the box in Figure 1. See text for definition of the Laurent, Bradelle, and Shediac upper crustal basement blocks. N.B. - New Brunswick, N.S. - Nova Scotia. 


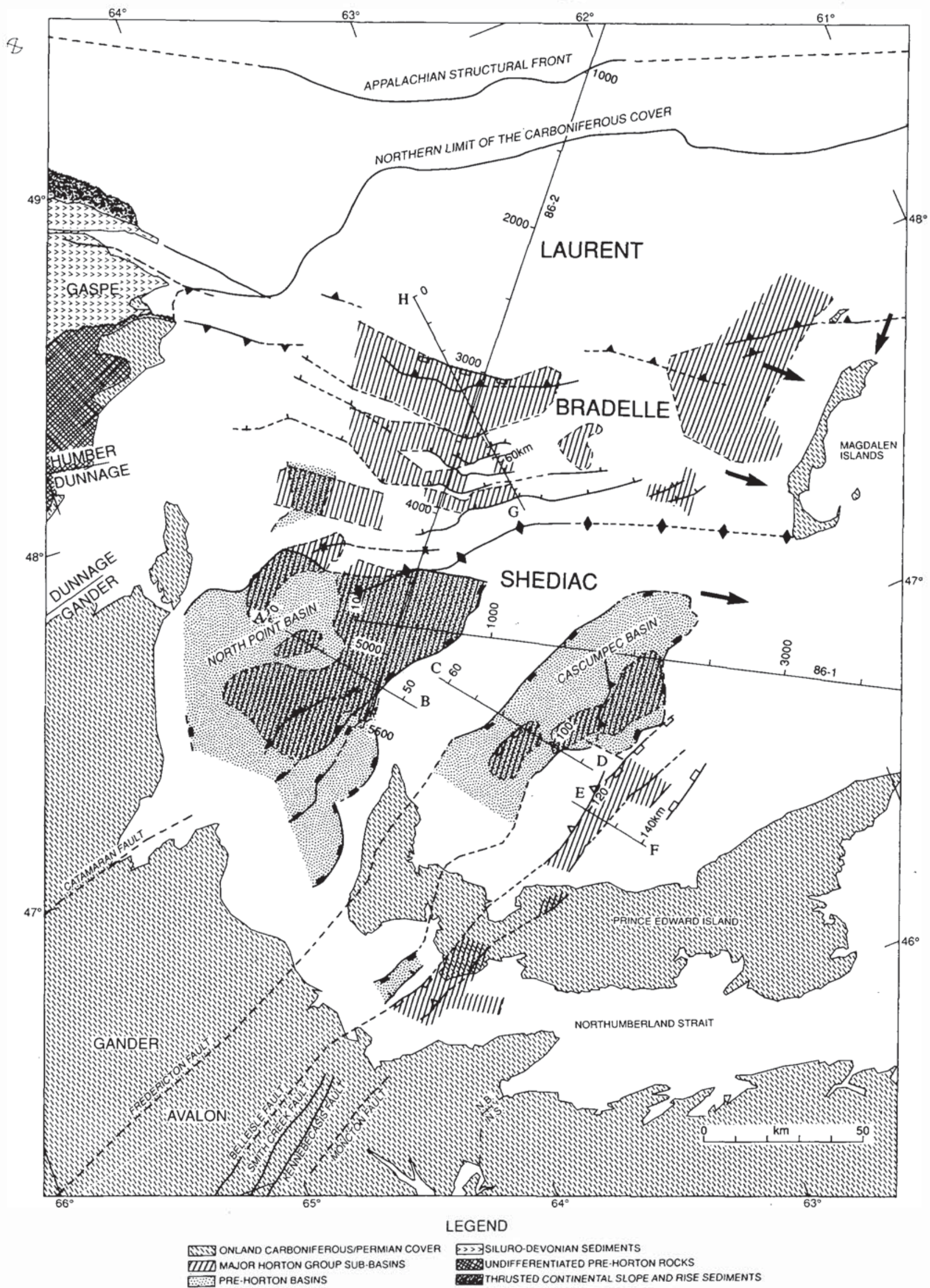

Fig. 3b. Sediment and basement rock distribution in the southwestem Gulf of St. Lawrence, Windsor Group and younger rocks removed. Boundaries of shaded areas: solid - known, dashed - approximate, none - unknown. Only areas of thick Horton Group strata are shown. 


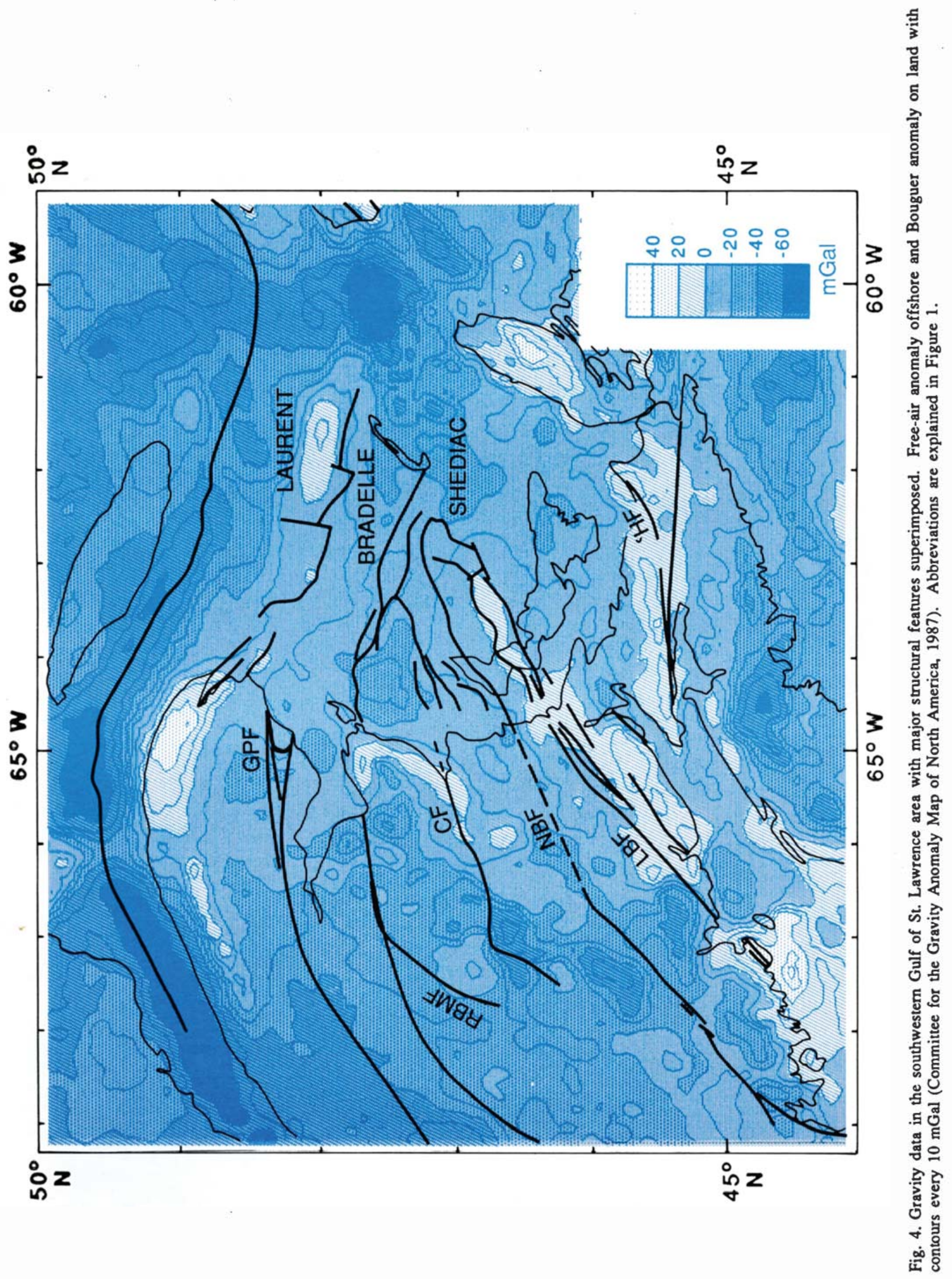




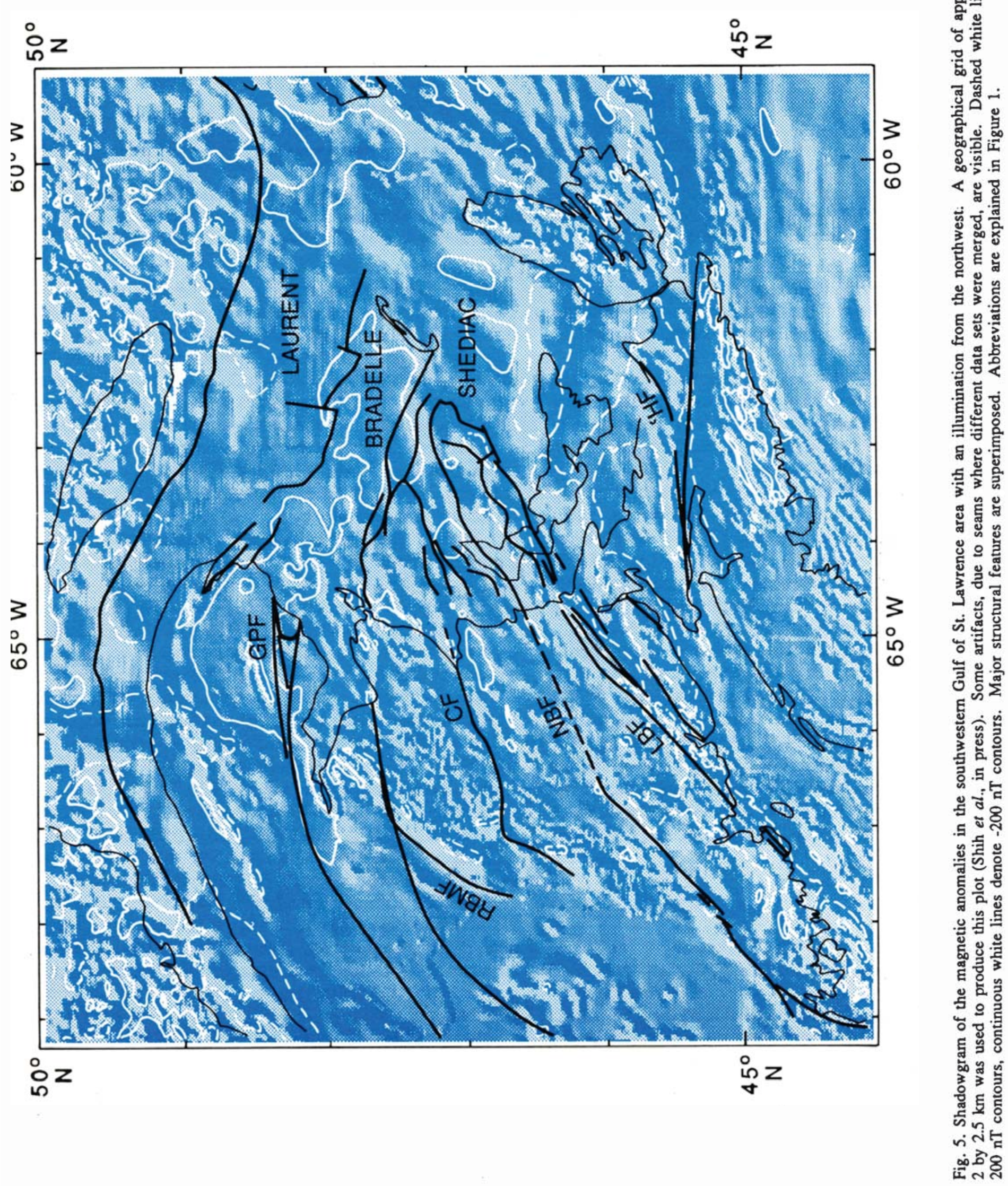


G

DISTANCE (kilometres)

H

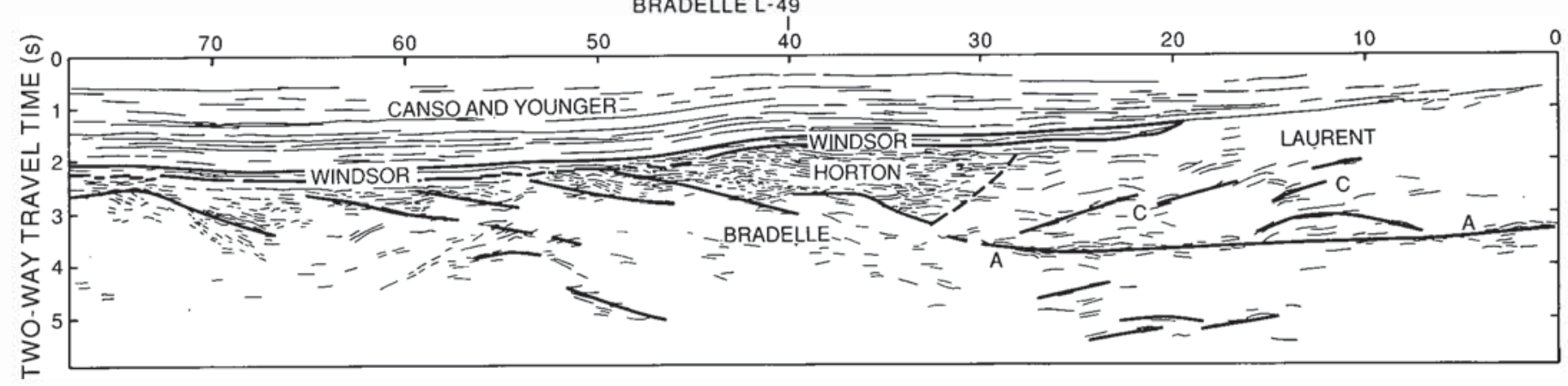

Fig. 6. Interpreted line drawing along the migrated profile G-H (for location see Figs. 3a, 3b). This profile images the Bradelle basement block, and straddles the Laurent/Bradelle boundary. Horton Group subbasins are interpreted beneath the Windsor Group sediments and above the north dipping reflections. This profile crosses line 86-2 (Fig. 7) in the vicinity of the Bradelle L -49 well, near $40 \mathrm{~km}$. See text for discussion of the labelled reflections.

overlie a sliver of material probably belonging to the Bradelle block. The lateral extent of the (A) reflections is shown by the two-way travel time contours at the base of the Laurent block (Fig. 3a).

There is a distinct difference in seismic character above and below the (A) reflections (Fig. 6). Above them, the discontinuous and chaotic reflections (C) contrast with the rather nonreflective character of the Bradelle block, except for the continuous arcuate reflections (B) (Fig. 7).

The above observations suggest a boundary at this location. This interpretation contrasts with that of Marillier et al. (1989) who recognized one continuous unit above the Grenville lower crustal block. Our interpretation is supported by potential field data. The Laurent/Bradelle boundary is located immediately south of two positive gravity anomalies, and it is parallel to the gravity and magnetic anomalies (Figs. 4, 5).

The north dipping fault mapped along the southern edge of Laurent is not identified near the Gaspe Peninsula. There, the base of Laurent occurs at more than 4.5 seconds and the (A) reflections terminate along a line that extends southeastward from Cap de Gaspé into the Gulf of St. Lawrence (Fig. 3a). The limestone sequences mapped on land by Roksandic and Granger (1981) probably occur south of this line. It is not clear whether the abrupt termination of the (A) reflections is real, or is the result of a lack of seismic penetration due to the overlying limestone sequences.

\section{The Bradelle block}

Three major and several other minor north dipping reflections characterize this block (Figs. 3a, 6, 7). In places, these reflections extend to 4 seconds two-way travel time and were mapped for 20-25 km along several seismic profiles. They were correlated between seismic lines oriented northeast-southwest, especially east of line 86-2. The north dipping reflections are approximately parallel to the WNW-ESE oriented gravity and magnetic trends over Bradelle (Figs. 4, 5).

The north dipping reflections appear to correlate with the basal reflectors of several subbasins (Fig. 6). Continuous reflections on the southern flank of the subbasins indicate undeformed strata, probably of Horton Group age, whereas the lack of coherent reflections from the northern flank suggests significant deformation, not typically associated with normal faulting. The subbasins are local in extent, they were correlated for about 20 $40 \mathrm{~km}$ on adjacent seismic lines (Fig. 3b). Their time thicknesses generally range from 0.3 to about 0.8 seconds two-way travel time. In the vicinity of the Bradelle L- 49 well, the largest of these basins is over 1.3 seconds two-way travel time thick, and was mapped for at least $60 \mathrm{~km}$ along strike. The relationship between the north dipping reflections and the subbasins is not fully understood (see discussion).

The north dipping reflections may extend along strike to the northwest towards Gaspé (Fig. 3a), but seismic sections immediately east of the Gaspé Peninsula indicate that the southwest dipping structures identified on land by Roksandic and Granger (1981) continue offshore for at least $30 \mathrm{~km}$ to the southeast. The change of structure polarity in this area suggests a boundary, but we cannot locate it because of insufficient seismic data coverage.

The northwest-southeast oriented southern edge of the Bradelle block is defined by different seismic characteristics east and west of line $86-2$, but by continuous gravity and magnetic signatures. The lower limit of Bradelle is given by an abrupt increase in reflectivity as shown on 86-2 (Fig. 7). The reflections marking the base of the Bradelle block rise to the south to define the northern edge of an antiformal structure (reflections D) that we interpreted as a basement high (Fig. 3a). This structure loses its seismic character to the east, but gravity data suggest that it extends south of the Magdalen Islands (dashed antiform in Fig. 3a). We defined the southern boundary of Bradelle immediately north of this basement high. West of line 86-2, the southern boundary of the Bradelle block is marked by a synformal structure [reflections (E) in Fig. 7] that can be mapped for at least 40 $\mathrm{km}$ to the west.

The Magdalen Basin approaches its greatest depth near the Magdalen Islands. Immediately west of the islands, the basement deepens abruptly to the east as indicated by long arrows in Figures $3 \mathrm{a}$ and $3 \mathrm{~b}$. The basement surface extends below 5 seconds two-way travel time, the maximum recording time of the industry seismic reflection data in this area. 


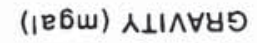
옹

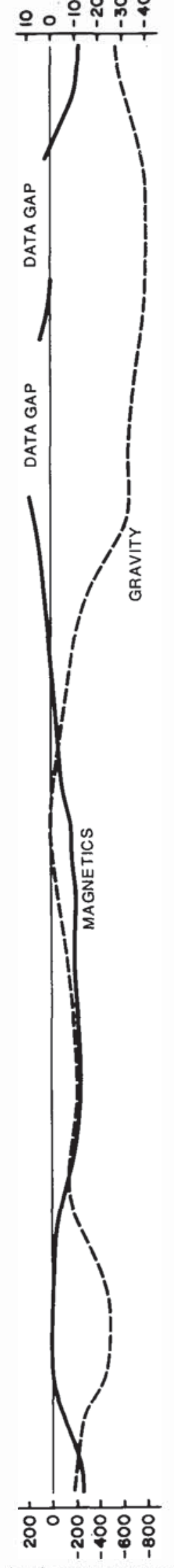

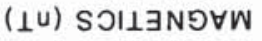

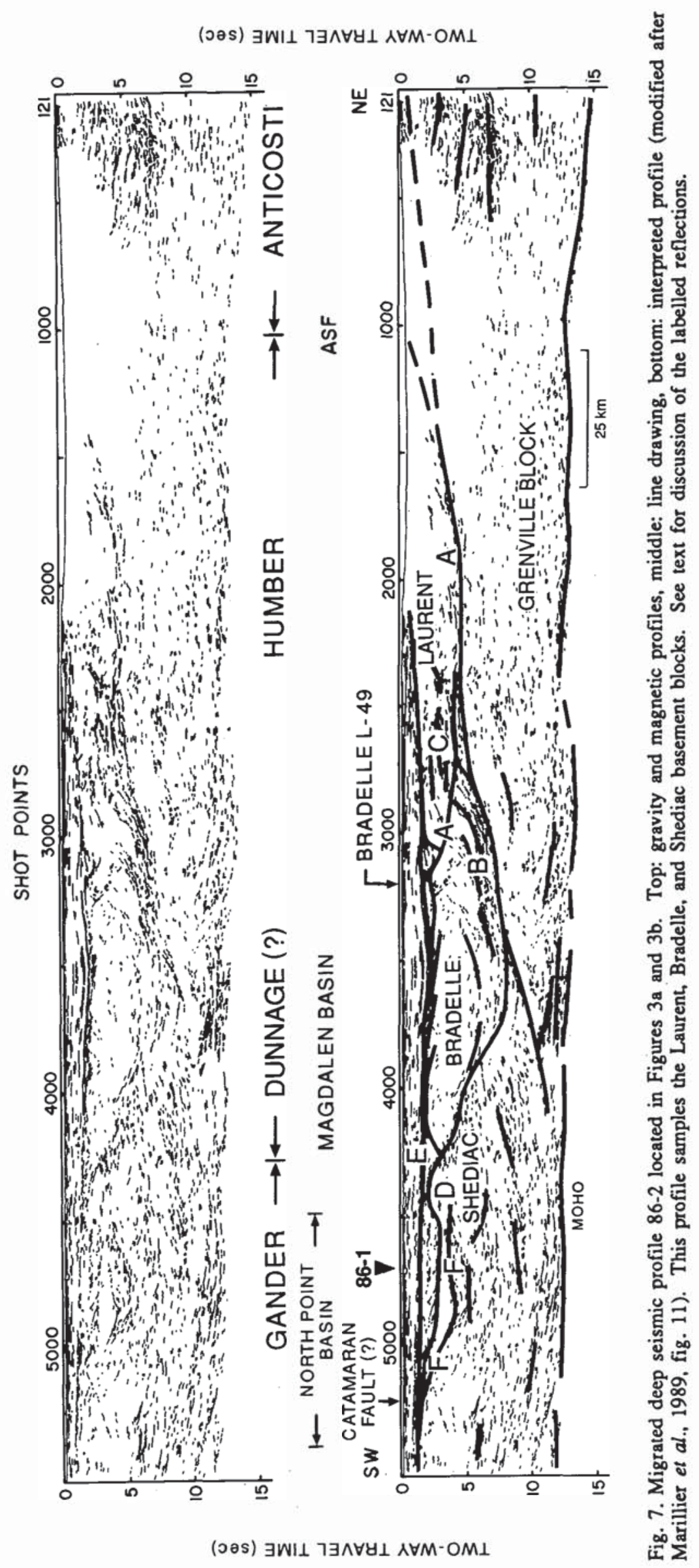



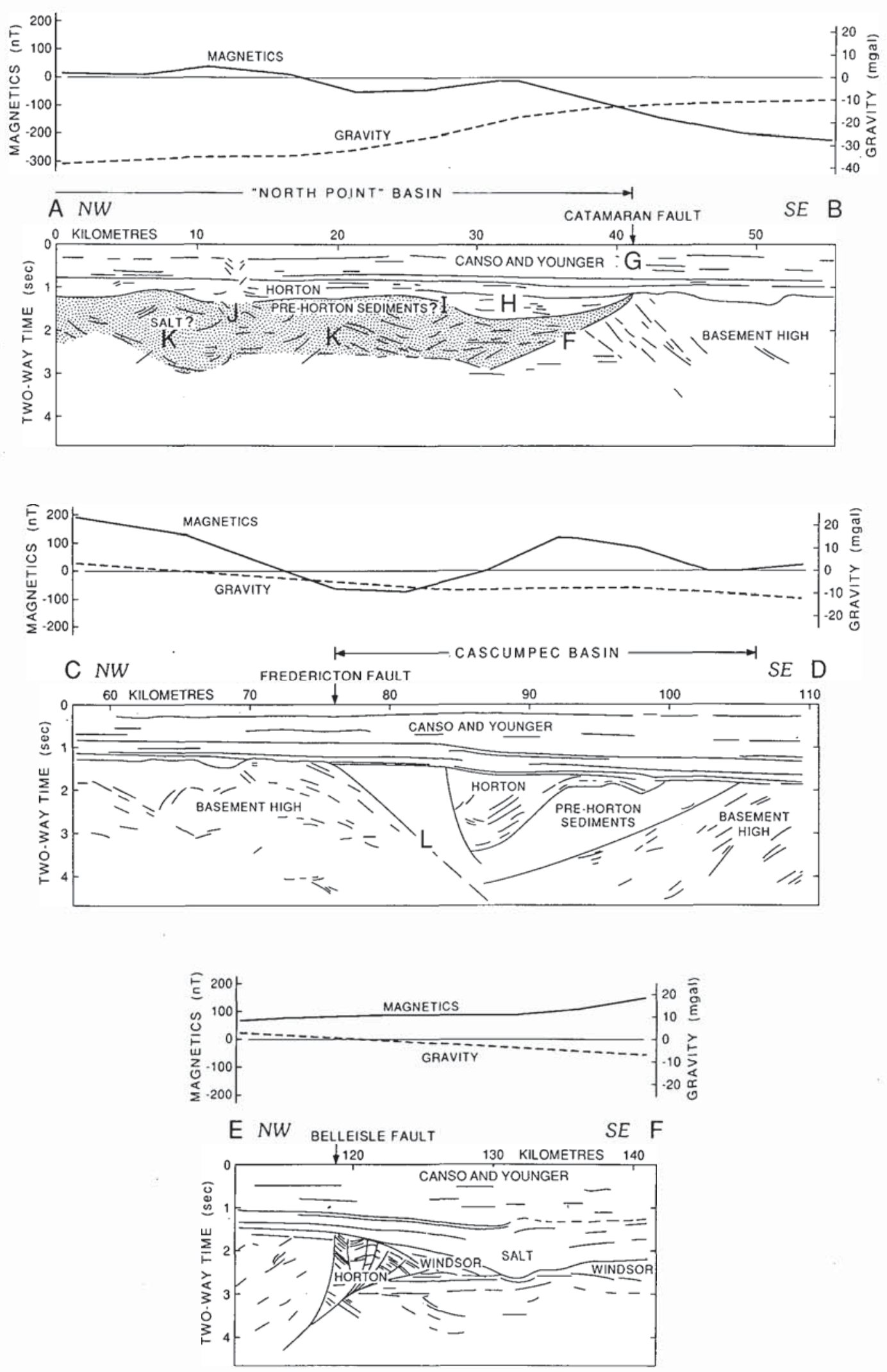

Fig. 8. Interpreted line drawings of the migrated seismic profiles A-B, C-D, and E-F, and corresponding gravity and magnetic profiles (for location see Fig3. 3a, 3b). These profiles are located within the Shediac basement block, and display the North Point and Cascumpec basins (profiles A-B and $C$ - $D$, respectively). In profile A-B, the shaded area indicates rocks tentatively interpreted as sediments of pre-Horton Group age. A compressional flower structure is shown along the extension of the Belleisle Fault in profile E-F. 


\section{The Shediac block}

The Shediac basement block is dominated by northeastsouthwest structural trends contrasting with the orientation of those of the Laurent and Bradelle blocks. The main features of this basement block are two pre-Carboniferous basins and an intermediate basement high (Fig. 3a, b). Three major faults that we correlate with major faults in New Brunswick transect this basement block. All the structural trends of the Shediac block end near the southem boundary of Bradelle. Unlike the Laurent and Bradelle blocks, Shediac does not have a well defined lower limit and may extend through the entire crust.

East of Miramichi Bay the seismic data indicate the presence of a thick sequence of sediments within a large basin. We called this basin the North Point Basin following Howie and Cumming (1967) who interpret a gravity low in this area as a basement graben.

The limits of the basin are well defined to the north, the east and the south. To the west, the basin edge cannot be constrained because of poor quality seismic data, but the gradually increasing gravity anomaly suggests that the basin shallows near the New Brunswick coast (Fig. 4). This is supported by a well located north of Miramichi Bay (Bartibog No. 1, Fig. 3a) and a second located south of Chaleur Bay (St. Isodore No. 1) that intersect Pennsylvanian sediments unconformably overlying pre-Carboniferous basement at less than $700 \mathrm{~m}$ (Ball et al., 1981). Along its southern edge, the basin is bounded by a series of northwest dipping faults which merge into a single fault to the northeast. One of these faults could be an extension of the Catamaran Fault. The sediments are generally gently folded, horizontal or slightly dipping toward the fault (Fig. 8, Section A-B, near $35 \mathrm{~km}$ ) suggesting the fault may be listric. The base of the basin was interpreted to be around 2.7 seconds (see Figs. 8,9). Along the southeast edge of the North Point Basin, the single fault flattens at depth and it merges with reflections (F) that define a surface which was mapped under the eastern end of the basin (two-way travel time contours in Fig. 3a). This surface may represent a decollement which was active during the formation of the basin.

The North Point Basin is overlain by 1.0 to 1.8 seconds twoway travel time of flat lying reflections $(G)$ and discontinuous reflections $(\mathrm{H})$. Beneath reflection (I), a marked unconformity, are short discontinuous reflections at various attitudes suggesting that the rocks experienced more tectonism than the overlying younger strata. At $13 \mathrm{~km}$, the up-tumed reflections (J) are reminiscent of diapiric structures, and possible salt pillows are indicated by reflections $(\mathrm{K})$. A southeast dipping fault cutting through the entire section may also be present between the (J) and (K) reflections.

We estimated the age of the North Point Basin strata on the basis of stratigraphic control, reflection character and seismic velocities. The sediments corresponding to the $(\mathrm{G})$ reflections were correlated with the Canso Group and younger strata by direct correlation with the Bradelle L- 49 well (Hudson's Bay Oil and Gas Company Limited, 1973). The discontinous (H) reflections are of medium to high amplitude below the Canso Group sediments. Sediments displaying this seismic character beneath Windsor Group or younger sediments, were assigned to the
Horton Group based on seismic data tied to the Bradelle L-49 (Hudson's Bay Oil and Gas Company Limited, 1973) and Irishtown No. 1 (Shell Canada Limited, 1974) wells (Fig. 3a). In this case, it is not possible to tie the deep North Point Basin sediments to any well. Seven refraction profiles across the North Point Basin (Hobson, 1966; Hobson and Overton, personal communication) indicate that rocks below the (I) unconformity have velocities of $6.1 \mathrm{~km} / \mathrm{s}$ or more. Because these velocities are much higher than those observed in Carboniferous sediments (Hobson and Overton, 1973), and because they are underlying possible Horton Group strata, we tentatively defined these rocks as preHorton Group rocks. The age of these sediments and their nature are dealt with more fully in the discussion.

The basement high southeast of the North Point Basin is a prominent feature in the central part of the Shediac block (Fig. 3a). The high is bounded to the southeast by a fault that extends to about 4.5 seconds two-way travel time (reflections L in Fig. 8 (C-D) and Fig. 9). This fault is important for three reasons: (1) it marks the southem boundary of the basement high, (2) it occurs at the surface location of the Moho offset identified by Marillier et al. (1989), and (3) it occurs at the location where the overlying Carboniferous sediments begin to thicken towards the south (Fig. 9). Continuity of the southern edge of the basement high to the southwest is indicated by southeast dipping reflections extending to depth in the Northumberland Strait (Fig. 3a). The extension of the Fredericton Fault to this area is supported by gravity and magnetic data. Therefore, we suggest that the Fredericton Fault extends northeastward beyond Prince Edward Island, and bounds the prominent basement high to the southeast.

We called a narrow basin that extends northeast of Cascumpec Bay, Prince Edward Island (Fig. 3a) the Cascumpec Basin (Fig. 3b). The sediments in this basin are poorly reflective, and they lack the Horton Group character as noted above (Figs. $8,9)$. We interpreted them to be pre-Horton Group strata. A subbasin, bound to the northwest by a normal fault (Fig. 8, C-D, $84 \mathrm{~km}$ ), and probably filled with Horton Group sediments, is superimposed on the Cascumpec Basin.

Southeast of the Cascumpec Basin, a basement high generally lacking reflections is marked by a positive gravity anomaly (Fig. 4). The anomaly is not apparent on Figure 8 (C-D) because the seismic line crosses the extreme northeastern edge of the basement high. Along the southeastern boundary of the high a fault displays a throw of about 1 second (equivalent to more than $2 \mathrm{~km}$ ), with thick faulted Horton Group and folded Windsor Group strata to the southeast (Fig. 8,E-F, 118km). Some seismic sections which show basement rocks thrust southeastward over these sediments indicate reverse movement along this fault. Probable flower structures suggest strike-slip movement (Fig. 8, section E-F). To the northeast, the throw across the fault dies out gradually, and the fault is no longer clearly defined.

Four major faults occurring on land, the Belleisle, Smith Creek, Kennebecasis and the Moncton faults (Foley, 1989), appear to extend to the Northumberland Strait where we mapped several faults (Fig. 3a). The Belleisle Fault may correlate with either one of two normal faults in the Northumberland Strait. We favour its correlation with the southern fault because the inferred Carboniferous movement along the Belleisle Fault in southern 


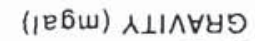
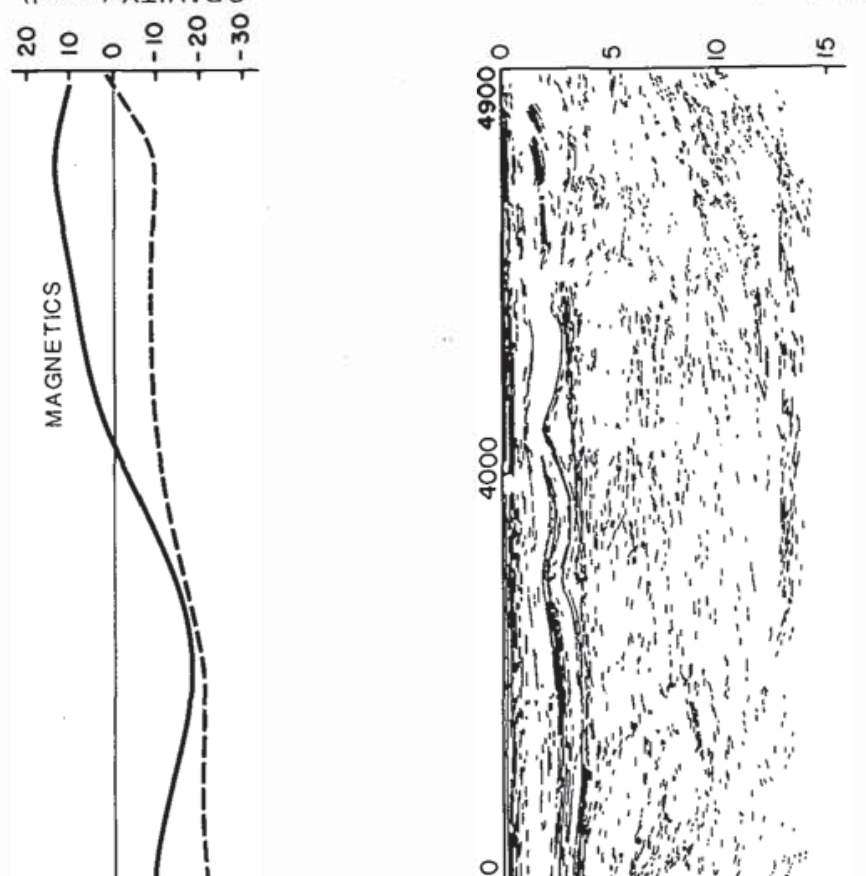

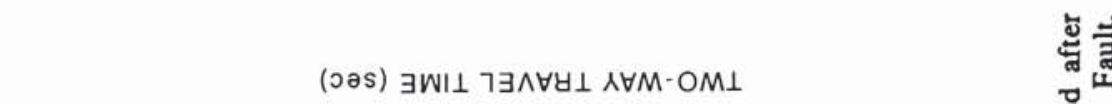
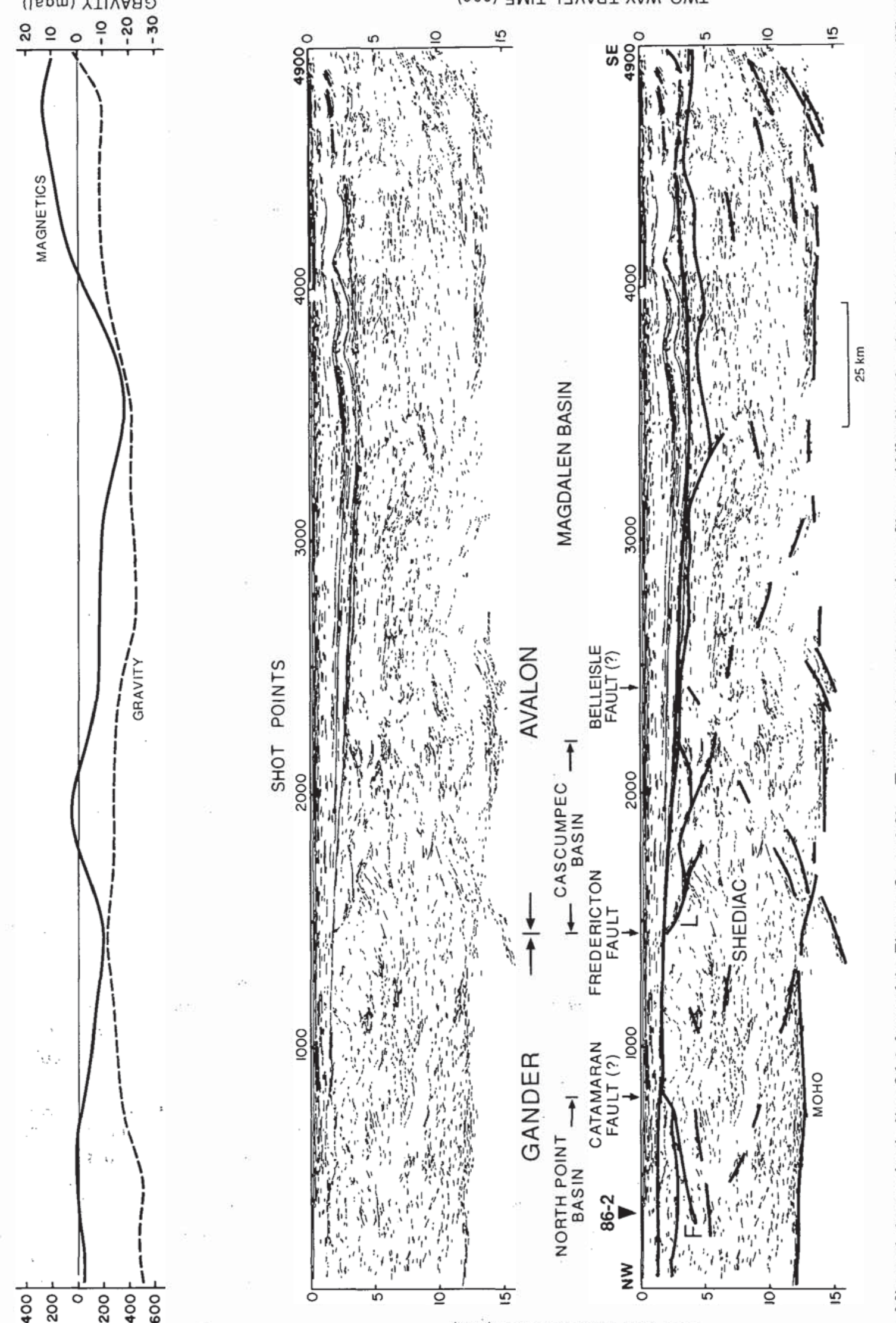

1
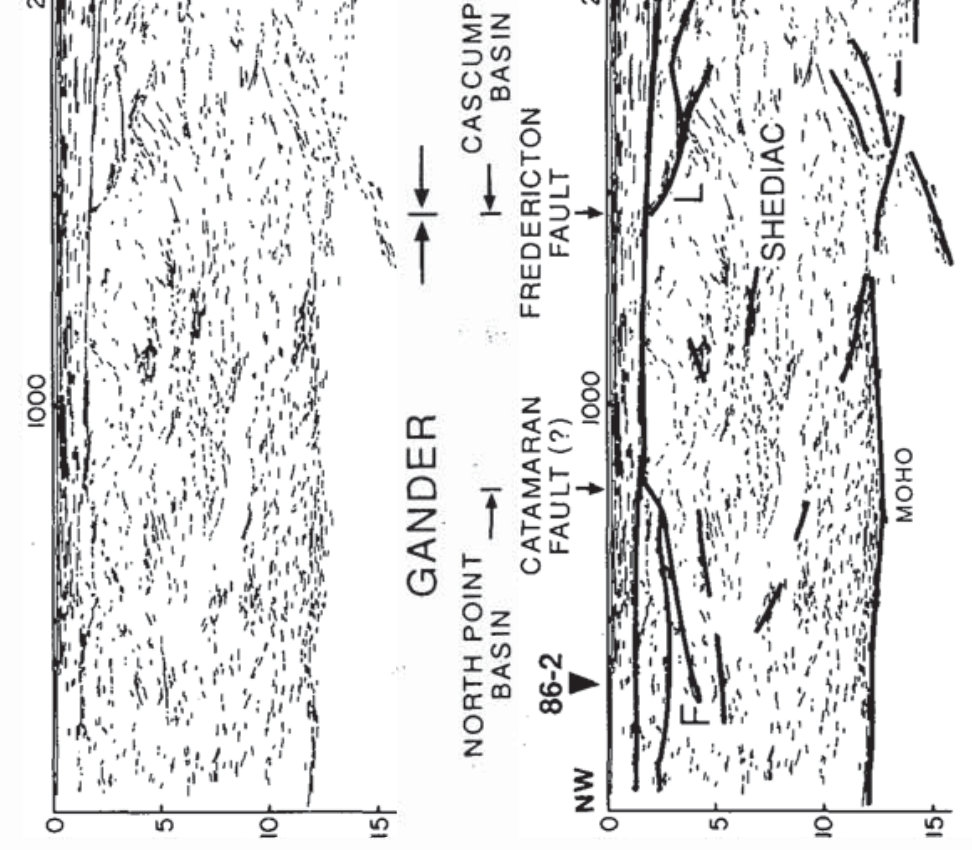

홍

乙

है

궁.

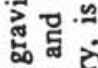

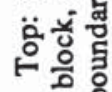

लिं.

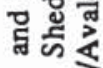

ก๊

के पे

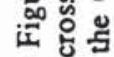

토 응

퐁

은

ฌ.

号

守

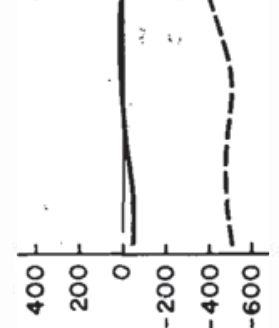

(วəs) $\exists W I \perp 7 \exists \wedge \forall \forall \perp \wedge \forall M-O M \perp$

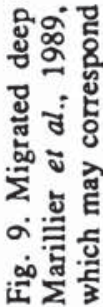


New Brunswick is down to the south (C. St. Peter, personal communication, 1989). Moreover, seismic reflection data on Prince Edward Island indicate that this fault extends between the Porthill No. 1 well and the MacDougall No. 1 and Wellington No. 1 wells (Fig. 3a) as suggested by Webb (1969). Basement was drilled at $1372 \mathrm{~m}$ in the Porthill No. 1 well, but it was not reached at depths of more than $2757 \mathrm{~m}$ and $2945 \mathrm{~m}$ respectively in the other two wells (Howie and Cumming, 1963). Further northeast, the seismic data indicate a similar relationship (see Fig. 8, E-F), suggesting continuity of the Belleisle Fault in this area.

On the basis of aeromagnetic data in eastern New Brunswick and the southwestern Gulf of St. Lawrence, Bhattacharyya and Raychaudhuri (1966) infer a series of subparallel, elongated, fault bounded, basement blocks. Their faults are approximately parallel to the structures we mapped with seismic data. One of their faults, which crosses the Northumberland Strait and Prince Edward Island, coincides with the fault we interpreted as the northeast extension of the Belleisle Fault. The boundary between their magnetic units II and III coincides with our extension of the Fredericton Fault across Prince Edward Island, but not in New Brunswick. In this area, the interpretation of Thomas and Willis (1989), using gravity data, suggests a crustal discontinuity close to our proposed extension of the Fredericton Fault.

Bhattacharyya and Raychaudhuri (1966) also observe an elongated magnetic unit that runs north of the northern tip of Prince Edward Island, and extends to the southeast across the island. We did not observe in the seismic data any feature that could correspond to this unit. Figure 4 shows that it does not correspond to a major magnetic anomaly. It was hardly detectable on a shadowgram of the same data with an illumination from the northeast.

\section{DISCUSSION}

\section{Faulting style}

Although wrench faulting is common in southern New Brunswick (see, e.g., Webb, 1969) we did not observe much evidence for this kind of faulting in the southwestern Gulf of St. Lawrence, perhaps in part because such faulting is not imaged well on seismic data. The only structures suggesting strike-slip faulting are located either south of the Cascumpec Basin or west of the Magdalen Islands (Fig. 3a). In the Magdalen Islands area, west of the steeply dipping basement, the base Windsor Group reflector is affected by an east-west trending strike-slip fault zone and numerous smaller faults distributed over a large area. The faults have short throws and affect lower Windsor Group and older strata. The faults in this area do not appear to be related to strike-slip faults south of the Cascumpec Basin. South of the Cascumpec Basin, several faults display northwest dipping reverse faults and positive flower structures indicating compressional strike-slip movement (see Fig. 8, E-F). The faults extending to the southwest along the southeast edge of the basement high can be interpreted in terms of compressional strike-slip tectonics.

Where a strike-slip fault changes direction relative to the general strike-slip displacement direction, compressional or extensional features are usually observed (see, for example, Mann et al., 1983). If dextral strike-slip movement is assumed during the Carboniferous Period for the northeast striking Belleisle Fault (Bradley, 1982), the reverse displacement observed on and northeast of Prince Edward Island (Fig. 3a) may be explained by a general direction of relative strike-slip displacement, which is more eastward than this segment of the Belleisle Fault.

The throw of more than $2 \mathrm{~km}$ across the extension of the Belleisle Fault and the deformed pre-Windsor Group strata on its downthrown side suggest that this fault was a major transcurrent fault. The seismic data indicate that the fault was active after Horton Group deposition but before Windsor Group deposition. This faulting may have been associated with the regional preWindsor Group deformation episode in southem New Brunswick (Ruitenberg and McCutcheon, 1982).

The Belleisle and Fredericton faults, the southeast dipping reflection (two-way travel-time contours mapped between the Cascumpec Basin and the Magdalen Islands, Fig. 3a), and the area of steeply dipping basement west of the Magdalen Islands are aligned along a northeast direction. This alignment coincides with a hinge line separating thin Magdalen Basin strata to the northwest from much thicker strata to the southeast. This suggests continuity of post-Acadian faults along this trend.

Horton and pre-Horton Group subbasins in the Shediac block are generally bounded by normal faults striking northeast. The normal faults display considerable throw and, in several cases, fanning sediments dipping toward the normal faults are observed. The relative abundance of normal faults and the wide distribution of Horton subbasins (Fig. 3b) suggests that early development of the Magdalen Basin, at least in the southwest part of the Gulf of St. Lawrence, was primarily the result of widespread extension.

In the Bradelle block, the north dipping reflections of the Horton Group subbasins are not terminated abruptly but rather disappear gradually (Fig. 6). The overall shape of the subbasins suggests that they are half grabens. However, in places the basal reflections of the subbasins extend beneath the next basin to the north, suggesting that the basal reflections may be reactivated thrust faults (of Acadian age?) over which Horton sediments were deposited during later extension.

\section{The "Canso Fault"}

The proposed "Canso Fault" (Barr and Raeside, 1986; McCutcheon and Robinson, 1987) is a dextral strike-slip fault that passes through the Strait of Canso and extends to the northwest in the vicinity of Prince Edward Island. This fault was introduced to take into account the offset of Gander or equivalent rocks in Cape Breton Island and Newfoundland with those in New Brunswick. Displacement along this fault is estimated to be up to $200 \mathrm{~km}$ (McCutcheon and Robinson, 1987). If the "Canso Fault" was active during the Acadian orogeny (Stockmal et al., 1990), the surface trace of the Fredericton Fault should display a right lateral offset, since it (the Norumbega-Fredericton Fault) is interpreted as a pre-Silurian suture (Ludman, 1986; Fyffe and Fricker, 1987). The northern extension of the Fredericton Fault that we propose rules out such an offset. The proposed amount 
of movement along the "Canso Fault" should have been accompanied by significant deformation which we do not observe. Generally, the seismic data in the Shediac block do not show any evidence for northwest trending faults or shear zones. We infer from Figures $3 \mathrm{a}$ and $3 \mathrm{~b}$ that, if such a fault does exist, it must occur along or north of the Bradelle/Shediac boundary.

A pre-Carboniferous restoration of Cape Breton Island's position to the northeast superimposes the "Canso Fault" on the Bradelle/Shediac boundary (Stockmal et al., 1990). This is consistent with the contrasting basement trends observed on each side of this boundary. Potential field data suggest that this boundary is an extension of the Grand Pabos Fault in southern Gaspé (see section on terrane boundaries). Malo and Beland (1989) estimated $155 \mathrm{~km}$ of combined dextral displacement during the Acadian orogeny along the Grand Pabos and two other faults in southern Gaspé (Fig. 1). The restoration of Stockmal et al. (1990) could be modified by extending the "Canso Fault" further to the northwest and linking it to the Grand Pabos Fault.

\section{The North Point Basin}

The $-40 \mathrm{mGal}$ gravity low over the North Point Basin is interpreted to be due to a granitic pluton (Goodacre and Nyland, 1966) or a Carboniferous basement graben containing evaporites (Howie and Cumming, 1967). We interpreted the presence of pre-Carboniferous rocks in the North Point Basin on the basis of reflection patterns typical of sediments, high seismic velocities $(6.1-6.6 \mathrm{~km} / \mathrm{s})$ in these rocks, and the inferred Horton Group age of the overlying rocks. The diapiric like structures suggesting salt tectonics below reflection (I) (Fig. 8) and the gravity low over this basin, suggest the presence of a significant amount of salt. However, the high seismic velocities of these rocks correspond to pre-Carboniferous basement velocities rather than to salt. Horton Group salt deposits are known in northern New Brunswick, northern Nova Scotia and Prince Edward Island (Howie, 1988), but pre-Horton salt has not been reported.

In modelling the North Point gravity anomaly, Goodacre and Nyland (1966) inferred a granitic body with a density contrast of $-0.1 \mathrm{~g} / \mathrm{cm}^{3}$ with respect to the surrounding basement. Thomas and Willis (1989) adopted a value of $2.74 \mathrm{~g} / \mathrm{cm}^{3}$ for the density of the country rocks in southwestem New Brunswick whereas the Devonian Saint George Batholith had a measured mean density of $2.61 \mathrm{~g} / \mathrm{cm}^{3}$. Thus, if the reflections below the (I) reflections in the North Point Basin represent basement, it is also possible that a granitic mass accounts for the gravity low.

\section{Terrane boundaries}

Some structures in the Shediac block are unequivocally the extension of structures recognized in southern and central New Brunswick. Consequently, the basement rocks of Shediac belong to either the Gander or Avalon terranes. The boundary between these two terranes is difficult to establish seismically. The Gander/Avalon boundary in New Brunswick is defined as either the Fredericton Fault (Williams, 1979; Williams and Hatcher, 1983; Ludman, 1986) or as the Belleisle Fault (Haworth and LeFort, 1979). Thomas and Willis (1989) proposed on the basis of gravity and aeromagnetic maps, that the Fredericton Fault is associated with a crustal boundary, and that it extends northeasterly to Prince Edward Island. The extension of the Fredericton Fault that we propose extends beyond Prince Edward Island, and it corresponds to southeast dipping reflections (L) on 86-1 (Fig. 9, shot point 1450) also suggesting that this fault is associated with a crustal boundary. However, the Belleisle Fault zone also extends beyond Prince Edward Island and is the locus of major pre-Windsor Group movement. The trend of the Belleisle Fault crosses line 86-1 (Fig. 9, shot point 2450) at the location corresponding to northwest dipping reflections identified by Marillier et al. (1989). Therefore, either fault could be considered for a terrane boundary. At depth, the Gander/Avalon boundary is marked by a Moho offset along 86-1 below the Fredericton Fault, suggesting that the boundary cuts through the entire crust as it does in other places in the Northern Appalachians (Keen et al., 1986; Marillier et al., 1989).

The Gander/Dunnage boundary in New Brunswick is approximated by the east-west segment of the Rocky BrookMillstream Fault (Fig. 1) (Williams, 1979; Williams and Hatcher, 1983). The extension of this fault into the Gulf of St. Lawrence is unclear, but its location suggests extension along the Bradelle/ Shediac boundary (see Fig. 1).

The northern boundary of the Dunnage Terrane is the Baie Verte-Brompton line (BVBL) (Fig. 1) (Williams and St-Julien, 1982). Since we do not have seismic data across the Dunnage/ Humber boundary in southern Gaspé, we cannot compare its seismic expression there with the data in the Gulf. Potential field data suggest that the rocks causing the gravity and magnetic anomalies in Gaspé extend to the southeast in the Gulf (Figs. 4, 5). The laterally varying depths or thicknesses of these rocks may account for the fluctuating gravity anomalies. To the south, a strong negative magnetic anomaly extending from Gaspé falls almost exactly within the limits of the Bradelle block.

These observations lead to the following possibilities: (a) the continuity of the gravity and magnetic anomalies from Gaspé into the Gulf may indicate that both the Laurent and Bradelle blocks belong to the Humber Terrane, and that the Dunnage Terrane does not extend into the Gulf; (b) the BVBL in southem Gaspé is not correctly located or does not represent the true location of the Humber/Dunnage boundary at depth, and the Laurent/Bradelle boundary is the location of the buried BVBL in the Gulf; and (c) the Humber/Dunnage boundary is correctly located in southem Gaspé, and the offshore extension of the boundary is expected to be located somewhere in the Bradelle block.

Alternative (a) implies that some of the Humber rocks lie above the Central crustal block, which underlies the Gander Terrane in most of the northern Appalachians (Keen et al., 1986; Marillier et al., 1989). This configuration was deemed unlikely by Marillier et al. (1989), but would be possible if the juxtaposition of the various terranes was considerably modified after the Taconic orogeny (e.g., along the Grand Pabos Fault and its possible extension along the Bradelle/Shediac boundary). According to altemative (b) both the Humber and the Dunnage terranes may occur in the Gulf if the Laurent/Bradelle boundary is the buried BVBL. A possible location for the continuation of 
the BVBL in Gaspe is along the southern limit of the positive gravity anomalies in northern Gaspe and the Laurent block (Fig. 4). Evidence to support the Laurent/Bradelle boundary as the buried BVBL may be found on the deep seismic profile 86-2 (Marillier et al., 1989). This line shows southwest dipping reflections [Reflections (B) in Fig. 7] near the northern limit of Bradelle. These reflections may represent the dipping ophiolitic complexes and/or the metaclastic rocks and olistostromes that are characteristic of the Baie Verte-Brompton line. The implication of altemative (c) is that the potential field anomalies are not indicators of the terrane locations, and the Humber/Dunnage boundary is not associated with a seismic discontinuity. In the case of alternatives (a) and (c), the Laurent/Bradelle boundary, an obvious structural boundary, would have unknown significance. At the present time we do not have enough data to either support or reject any of the three alternatives, although we prefer alternatives (a) and (b) because they rely on some geophysical data.

\section{Formation of the Magdalen Basin}

The evidence gathered from industry and deep seismic data in the southwestern Gulf of St. Lawrence is integrated in a development scheme of the Magdalen Basin as summarized in Figure 10. The purpose of this sketch is not to provide a new model for the formation of the Magdalen Basin, but merely to point out a few milestones in the basin development which can be inferred from our data compilation and other recent works (Marillier and Verhoef, 1989; Marillier et al., 1989).

During the Late Devonian-Early Carboniferous the crust was stretched and small basins developed (Horton Group subbasins, Fig. 3b). These basins are distributed over a large area which suggests widespread extension. Simultaneously, mafic and ultramafic rocks were intruded into the lower crust as suggested by Marillier and Verhoef (1989). During or immediately after this stretching phase, normal movement or strike-slip movement (Knight, 1983, p. 82) occurred to the east along a vertical or sub-vertical fault which cut through the entire crust. Such a fault is implied by the asymmetry of the Magdalen Basin as observed along 86-1, and by the fact that pre-Carboniferous basement is exposed in Cape Breton Island, approximately $12 \mathrm{~km}$ east of the southeastern end of 86-1. A possible candidate for this fault is the northern extension of the Hollow Fault west of Cape Breton Island. Strike-slip motion probably occurred along the Belleisle Fault prior to Windsor Group deposition. After the stretching phase stopped, thermal relaxation caused slow subsidence of the crust, and the thick Carboniferous and Permian strata in the Magdalen Basin were deposited. The Hollow Fault bounding the basin to the southeast acted as a normal fault. Simultaneously, a hinge line developed near the Fredericton Fault, allowing asymmetric crustal subsidence. The hinge line coincides with the western limit of crustal underplating (Marillier and Verhoef, 1989).

McCutcheon and Robinson (1987) have argued that the pullapart model of Bradley (1982) should be dismissed because only limited strike-slip motion may have occurred along the Belleisle Fault after the Acadian orogeny (Devonian). Our data suggest that strike-slip movement occurred along this fault after the
A Late Devonian - Early Carboniferous (stretching)

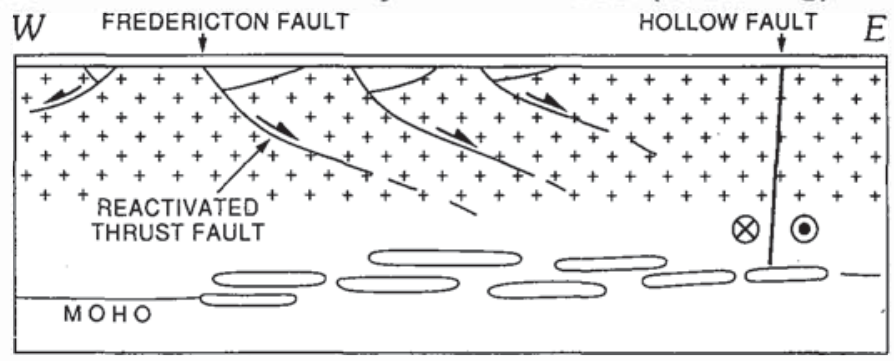

B Carboniferous - Permian (subsidence)

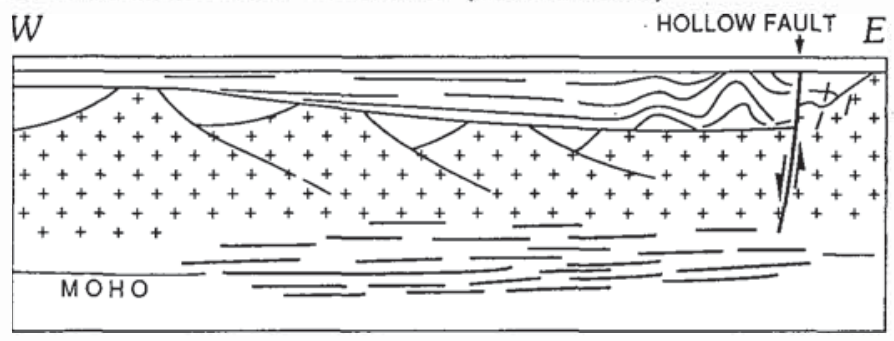

Fig. 10. Sketch showing some of the implications of our data interpretations for the two-step formation of the Magdalen Basin. (A) Stretching phase. Stretching of the crust produces normal faulting possibly along reactivated thrust faults. To the east the basin is bound by a sub-vertical strike-slip fault (Hollow Fault?). At the same time the crust is underplated by mafic/ultramafic rocks. (B) Thermal relaxation phase. Subsidence occurs while vertical movement along the east bounding fault accounts for asymmetric formation of the basin.

deposition of Horton Group strata (Late Devonian to Early Carboniferous) but before deposition of Windsor Group strata (Early Carboniferous to middle Carboniferous). Strike-slip faulting was preceded by stretching of the crust and normal faulting in an area northwest of the Belleisle Fault, the northwest boundary of the pull-apart model of Bradley (1982). The pullapart model as proposed by Bradley (1982) does not account for the widespread extension observed in the Gulf of St. Lawrence. The Magdalen Basin may rather have developed within an extensional environment and was subsequently deformed by strike-slip movements.

\section{CONCLUSIONS}

The basement rock trends and their subdivision into three upper crustal basement blocks as described in this study, bear on many aspects of local and regional geology, as well as on the tectonics of the Northern Appalachians. Some features are well defined, like the northeast extension of the general trends in New Brunswick, and the termination of these trends in the Gulf of St. Lawrence along the Bradelle/Shediac boundary. This change of trend direction suggests that it is a major boundary within the Appalachian orogen. It may correspond to the southern limit of either the Dunnage or Humber terranes. Thus the nature of the Bradelle basement block remains uncertain. The Gander/Avalon boundary occurs within the Shediac block, along the offshore extension of either the Fredericton Fault or the Belleisle Fault. This boundary coincides with a Moho offset, and thus it appears 
to affect the entire crust as is the case at other places in the Northern Appalachians.

In the southwestern Gulf of St. Lawrence, most of the faults in the Shediac block display normal movement (Late DevonianEarly Carboniferous), whereas some display strike-slip movement. In the Bradelle block, the north dipping reflections underlie half graben-like Horton Group subbasins. We interpreted this faulting style in both basement blocks to result from widespread stretching of the crust. Compressive strike-slip movement inferred from the seismic data along the Belleisle Fault suggests that this fault played a major role in the deformation of the basin, but was probably not one of the bounding faults predicted in the pull-apart model of Bradley (1982). The overall asymmetry of the Magdalen Basin suggests that a fault (the Hollow Fault?) bounded the basin to the east and acted as a subvertical normal fault allowing asymmetric subsidence of the Magdalen Basin.

\section{ACKNOWLEDGEMENTS}

Our thanks are due to the following companies or agencies for letting us have copies of seismic data: the Canada Oil and Gas Lands Administration (Ottawa and Halifax), CHEVRON (Calgary), the Department of Natural Resources and Energy of New Brunswick (Fredericton), the Department of Energy and Forestry of Prince Edward Island (Charlottetown), and the Department of Mines and Energy of Nova Scotia (Halifax). AMOCO (Calgary) allowed us to study at their premises some seismic profiles not released to the public. We thank J. Hunter and R. Gagne for unpublished refraction results in the Gulf, M. Malo and J. Beland for a pre-print of their recent paper, and L. Fyffe for stimulating discussions and his help in many respects. The manuscript was significantly improved by the scrutiny of A. Grant, D. Piper, D. Stewart and H. Miller. R. Howie shared with us his knowledge on Paleozoic sediments in the Gulf of St. Lawrence area, and M. Best provided his support in the initial gathering of seismic data. J. Verhoef and K. Shih helped to prepare the figures with the gravity and magnetic anomalies.

BALL, F.D., SULLIVAN, R.M., and PEACH, A.R. 1981. Carboniferous drilling project. New Brunswick Department of Natural Resources, Report of Investigation 18, 109 p.

BARR, S.M. and RAESIDE, R.P. 1986. Pre-Carboniferous subdivisions of Cape Breton Island, Nova Scotia. Maritime Sediments and Atlantic Geology, 22, pp. 252-263.

BHATTACHARYYA, B.K. and RAYCHAUDHURI, B. 1966. Aeromagnetic and geological interpretation of a section of the Appalachian belt in Canada. Canadian Journal of Earth Sciences, 4, pp. 1015-1037.

BRADLEY, D.C. 1982. Subsidence in late Paleozoic basins in the northern Appalachians. Tectonics, 1, pp. 107-123.

COMMITTEE FOR THE GRAVITY ANOMALY MAP OF NORTH AMERICA. 1987. Gravity anomaly map of North America, Boulder, Colorado. Geological Society of America, Digital data set.

FOLEY, S.L. 1989. Geology of the Stoney Creek Oil and Gas Field, and its implications regarding the tectonic evolution of the eastern Moncton Subbasin, New Brunswick. New Brunswick Department of Natural Resources and Energy, Minerals and Energy Division, Geoscience Report 89-1.

FYFFE, L.R. and FRICKER, A. 1987. Tectonostratigraphic terrane analysis of New Brunswick. Maritime Sediments and Atlantic Geology, 23, pp. 113-122.

GOODACRE, A.K. and NYLAND, E. 1966. Underwater gravity measurements in the Gulf of St. Lawrence. In Continental Drift. Edited by G.D. Garland. Royal Society of Canada, Special Publication Number 9, pp. 114-128.

HAWORTH, R.T. 1978. Interpretation of geophysical data in the northem Gulf of St. Lawrence and its relevance to lower Paleozoic geology. Geological Society of America, Bulletin 89. pp. 10911110.

HAWORTH, R.T. and LEFORT, J.P. 1979. Geophysical evidence for the extent of the Avalon zone in Atlantic Canada. Canadian Journal of Earth Sciences, 16, pp. 552-567.

HOBSON, G.D. 1966. GSC surveys Gulf area. Oilweek, August 22 , 1966, pp. 54-55.

HOBSON, G.D. and OVERTON, A. 1973. Sedimentary refraction seismic surveys, Gulf of St. Lawrence. In Earth Science Symposium on Offshore Eastem Canada. Edited by P.J. Hood, N.J. McMillan, and B.R. Pelletier. Geological Survey of Canada, Paper 71-23, pp. 325-336.

HOWIE, R.D. 1988. Upper Paleozoic evaporites of southeastern Canada. Geological Survey of Canada, Bulletin 380, 120 p.

HOWIE, R.D. and BARSS, M.S. 1975. Upper Paleozoic rocks of the Atlantic Provinces, Gulf of St. Lawrence and adjacent continental shelf. Geological Survey of Canada, Paper 74-30, 2, pp. 35-50.

HOWIE, R.D. and CUMMING, L.M. 1963. Basement features of the Canadian Appalachians. Geological Survey of Canada, Bulletin 89, 18 p.

-1967. Possible basement graben beneath Miramichi Bay, New Brunswick. Geological Association of Canada, Special Paper 4, pp. 283-292.

HUDSON'S BAY OIL AND GAS COMPANY LIMITED. 1973. HB Fina et al. Irishtown No. 1, Well History Report. Canada Oil and Gas Lands Administration.

KEEN,C.E., KEEN, M.J., NICHOLS, B., REID, I., STOCKMAL, G.S., COLMAN-SADD, S.P., O'BRIEN, S.J., MILLER, H., QUINLAN, G., WILLIAMS, H., and WRIGHT, J. 1986. A deep seismic reflection profile across the northern Appalachians. Geology, 14, pp. 141-145.

KNIGHT, I. 1983. Geology of the Carboniferous Bay St. George subbasin, westem Newfoundland. Mineral Development Division, Department of Mines and Energy, Government of Newfoundland and Labrador, Memoir 1,358 p.

LONCAREVIC, B.D., BARR, S.M., RAESIDE, R.P., KEEN, C.E., and MARILLIER, F. 1989. Northeastern extension and crustal expression of terranes from Cape Breton Island, Nova Scotia, using geophysical data. Canadian Journal of Earth Sciences, 26, pp. 2255-2267.

LUDMAN, A. 1986. Timing of terrane accretion in eastem and eastcentral Maine. Geology, 14, pp. 411-414.

MALO, M. and BELAND, J. 1989. Acadian strike-slip tectonics in the Gaspé region, Québec Appalachians. Canadian Journal of Earth Sciences, 26, pp. 1764-1777.

MANN, P., HEMPTON, M.R., BRADLEY, D.C., and BURKE, K. 1983. Development of pull-apart basins. Journal of Geology, 91 , pp. 529-554.

MARILLIER, F. and VERHOEF, J. 1989. Crustal thickness under the Gulf of St. Lawrence, Northern Appalachians, from gravity and deep seismic data. Canadian Journal of Earth Sciences, 26, pp. 
1517-1532.

MARILLIER, F., KEEN, C.E., STOCKMAL, G.S., QUINLAN, G., WILLIAMS, H., COLMAN-SADD, S.P., and O'BRIEN, S.J. 1989. Crustal structure and surface zonation of the Canadian Appalachians: Implications of deep seismic data. Canadian Journal of Earth Sciences, 26, pp. 305-321.

McCUTCHEON, S.R. and ROBINSON, P.T. 1987. Geological constraints on the genesis of the Maritimes basin, Atlantic Canada. In Sedimentary basins and basin-forming mechanisms. Edited by $\mathrm{C}$. Beaumont and A.J. Tankard. Canadian Society of Petroleum Geologists, Memoir 12, pp. 287-297.

ROKSANDIC, M.M. and GRANGER, B. 1981. Structural styles of Anticosti Island, Gaspé Passage and eastern Gaspé Peninsula inferred from reflection seismic data. In Field meeting, AnticostiGaspé, Quebec, 1981. Volume 2: Stratigraphy and Paleontology. Edited by P.J. Lespérance. International Union of Geological Sciences (IUGS) Submission on Silurian Stratigraphy and Ordovician-Silurian Boundary Working Group, pp. 211-221.

ROLIFF, R.A. 1962. The Maritimes Carboniferous basin of Eastem Canada. Geological Association of Canada, Proceedings, 14, pp. 21-41.

RUTTENBERG, A.A. and McCUTCHEON, S.R. 1982. Acadian and Hercynian structural evolution of southern New Brunswick. In Major Structural Zones and Faults of the Northern Appalachians. Edited by P. St-Julien and J. Beland. Geological Association of Canada, Special Paper 24, pp. 131-148.

SHELL CANADA LIMITED. 1974. Shell-SOQUIP-Amoco Bradelle L-49, Well History Report. Canada Oil and Gas Lands Administration.

SHIH, K.G., WILLIAMS, H.L., and MACNAB, R. In press. Magnetic anomalies and major structural features of southeastern Canada and the Atlantic Continental Margin. Geological Survey of Can- ada.

SOQUIP (Société Québéquoise d'Initiatives Pétrolières). 1987. Estuary and Gulf of Saint Lawrence, geological-geophysical-geochemical data integration. Geological Survey of Canada, Open File Report 1721, 75 p.

STOCKMAN, G.S., COLMAN-SADD, S.P., KEEN, C.E., MARILLIER, F., O'BRIEN, S.J., and QUINLAN, G.M. 1990. Deep seismic structure and plate tectonic evolution of the Canadian Appalachians. Tectonics, 9, pp. 45-62.

THOMAS, M.D. and WILLIS, C. 1989. Gravity modelling of the Saint George Batholith and adjacent terrane within the Appalachian Orogen, southem New Brunswick. Canadian Journal of Earth Sciences, 26, pp. 561-576.

WEBB, G.W. 1969. Paleozoic wrench faults in Canadian Appalachians. In North Atlantic Geology and Continental Drift. Edited by M. Kay. American Association of Petroleum Geologists, Memoir 12, pp. 754-786.

WILLIAMS, H. 1979. Appalachian orogen in Canada. Canadian Journal of Earth Sciences, 16, pp. 792-807.

WILLIAMS, H., and HATCHER, R.D., JR. 1983. Appalachian suspect terranes. In Contributions to the Tectonics and Geophysics of Mountain Chains. Edited by R.D. Hatcher, Jr., H. Williams and I. Zietz. Geological Society of America, Memoir 158, pp. 33-53.

WILLIAMS, H. and St-JULIEN, P. 1982. The Baie Verte-Brompton line: Early Paleozoic continent-ocean interface in the Canadian Appalachians. In Major Structural Zones and Faults of the Northem Appalachians. Edited by P. St-Julien and J. Beland. Geological Association of Canada, Special Paper 24, pp. 177-207.

WILLIAMS, H., COLMAN-SADD, S.P., and SWINDEN, H.S. 1988. Tectono-stratigraphic subdivisions of central Newfoundland. Geological Survey of Canada, Paper 88-1B, pp. 91-98. 